\title{
Molecular recognition of AT-DNA sequences by the induced CD pattern of dibenzotetraaza[14]annulene (DBTAA)-adenine derivatives
}

\author{
Marijana Radić Stojković1 ${ }^{1}$, Marko Škugor ${ }^{1}$, Łukasz Dudek ${ }^{2}$, Jarosław Grolik², \\ Julita Eilmes $^{2}$ and Ivo Piantanida ${ }^{* 1}$
}

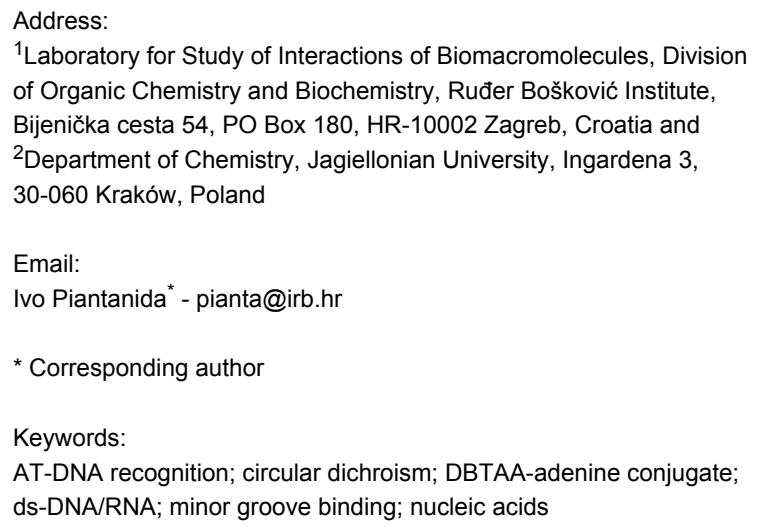

${ }^{1}$ Laboratory for Study of Interactions of Biomacromolecules, Division of Organic Chemistry and Biochemistry, Ruđer Bošković Institute, Bijenička cesta 54, PO Box 180, HR-10002 Zagreb, Croatia and ${ }^{2}$ Department of Chemistry, Jagiellonian University, Ingardena 3, 30-060 Kraków, Poland

Email:

Ivo Piantanida* - pianta@irb.hr

* Corresponding author

Keywords:

AT-DNA recognition; circular dichroism; DBTAA-adenine conjugate; ds-DNA/RNA; minor groove binding; nucleic acids

Beilstein J. Org. Chem. 2014, 10, 2175-2185.

doi:10.3762/bjoc. 10.225

Received: 12 May 2014

Accepted: 27 August 2014

Published: 12 September 2014

This article is part of the Thematic Series "Nucleic acid chemistry".

Guest Editor: H.-A. Wagenknecht

(C) 2014 Stojković et al; licensee Beilstein-Institut.

License and terms: see end of document.

\begin{abstract}
An investigation of the interactions of two novel and several known DBTAA-adenine conjugates with double-stranded DNA and RNA has revealed the DNA/RNA groove as the dominant binding site, which is in contrast to the majority of previously studied DBTAA analogues (DNA/RNA intercalators). Only DBTAA-propyladenine conjugates revealed the molecular recognition of AT-DNA by an ICD band pattern $>300 \mathrm{~nm}$, whereas significant ICD bands did not appear for other ds-DNA/RNA. A structure-activity relation for the studied series of compounds showed that the essential structural features for the ICD recognition are a) the presence of DNA-binding appendages (adenine side chain and positively charged side chain) on both DBTAA side chains, and b) the presence of a short propyl linker, which does not support intramolecular aromatic stacking between DBTAA and adenine. The observed AT-DNA-ICD pattern differs from previously reported ss-DNA (poly dT) ICD recognition by a strong negative ICD band at $350 \mathrm{~nm}$, which allows for the dynamic differentiation between ss-DNA (poly dT) and coupled ds-AT-DNA.
\end{abstract}

\section{Introduction}

The majority of natural and artificial applications involving small molecule-DNA/RNA recognition depend on several noncovalent binding modes. Typical examples are double-stranded (ds) DNA/RNA intercalation, minor or major groove binding, and external electrostatic binding [1]. However, non-covalent interactions involving small molecules $\left(M_{\mathrm{w}}<600\right)$ can only rely on a small number of interacting groups, while the steric parameters of DNA/RNA binding sites are also quite limited. 
Nevertheless, the dynamic nature of nucleic acids, combined with structural differences between various DNA/RNA sequences, offer numerous highly interesting targets. Within the last two decades, the design of small binding molecules has mostly relied on the three-dimensional recognition of various targeted DNA/RNA sites [2,3], frequently relying upon new knowledge gained from supramolecular chemistry [4].

Among the large number of DNA/RNA sequences of biochemical interest, long homogeneous AT tracts have attracted significant attention as small molecule targets. An illustrative natural example can be found in proteins which use selective binding interactions of an arginine-rich side arm inside the AT sequence minor groove to broaden the related DNA major groove, within which the protein biological action takes place [5]. However, the majority of known small molecules are not able to distinguish AT tracts by length and composition. This has been demonstrated, for instance, by the inability to distinguish between longer tracts (more than 20-30 base pairs) of homo and alternating distribution of AT base pairs.

Our recent studies revealed a novel class of cyanine dyes characterized by bulky phosphonium substituents as intriguing AT binders, which showed very rare kinetic differentiation between alternating- and homo-AT-DNA sequences [6]. Moreover, these dyes efficiently entered cells and were shown to be non-toxic, mitochondria-specific fluorescent markers [7]. Previous studies also revealed the advantage of nucleobase incorporation in small molecule structures for the recognition of complementary nucleotides/polynucleotides [8-10]. Recent studies of the novel
DBTAA-adenine conjugates AP3 and AP6 (Scheme 1) showed a highly selective binding of only AP3 to poly dT among all other ss-DNA/RNA, as characterized by the induction of a specific CD band response [11]. Observed oligo dT specificity provoked the intriguing question of whether such a specificity would be observed in double-stranded AT-DNA sequences. The experimental design to investigate this question was supported by the aforementioned importance of AT tracts and the selectivity of cyanine dyes. On this basis, we were inspired to prepare the novel binders AP5 with a DBTAA-adenine linker length between AP3 (oligo dT specific) and AP6 (oligo-dT inert) and AP3am, in which pyridinium is exchanged by a permethylated amine, with the aim of determining the importance of aromatic stacking interactions. The results were compared with the reference APH (lacking adenine) and previously studied DP77 [12] (Scheme 1), which, having pyridinium instead of adenine, can also be regarded as a reference structure. Double-stranded DNA/RNA targets chosen for this study are long ( $<100$ base pairs) synthetic polynucleotides poly $\mathrm{dG}-$ poly $\mathrm{dC}$, poly dA-poly dT, poly dAdT-poly dAdT and poly rA-poly $\mathrm{rU}$, each associated with specific structural properties of the minor/major groove as the anticipated binding site (APH, AP3, AP6 didn't intercalate into ct-DNA [11]). Namely, parameters such as the groove width and depth, steric obstructions like the amino groups of guanine, H-bonding patterns, as well as polynucleotide charge density and the curvature of the ds-helix backbone all differ significantly across the double stranded examples mentioned above (Table S1, Supporting Information File 1). The choice of long polynucleotides ensures that significant binding of the DBTAA moiety at the ends of the double

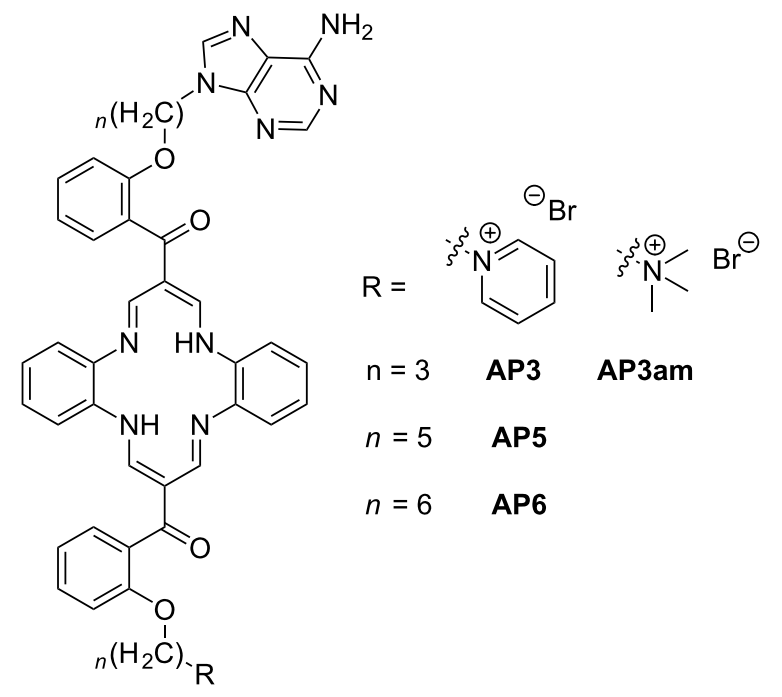<smiles>CCC[n+]1ccccc1</smiles>

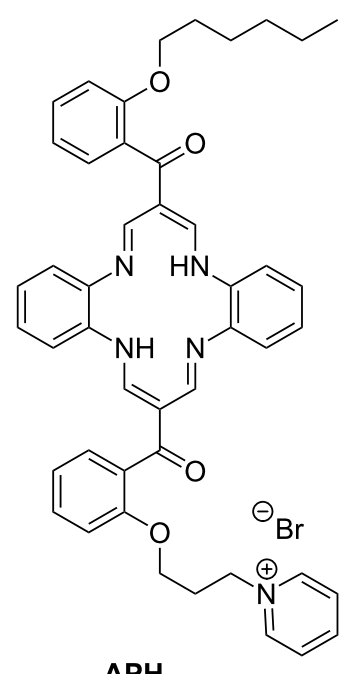

Scheme 1: Studied DBTAA-adenine conjugates (AP3, AP3am, AP5, AP6) [11], and the reference compounds lacking adenine (APH [11], DP77 $[12,13])$. 
strands ("capping") can be neglected and that our investigations indeed sense the differences of the secondary structure (from minor/major groove) of the studied DNA and RNA sequences.

\section{Results and Discussion Synthesis}

The synthetic routes to the new adenine-DBTAA conjugates AP3am and AP5 are summarized in Scheme 2, the details of which are given in the Experimental section.

\section{Spectroscopic characterisation of DBTAA derivatives in aqueous medium}

Novel compounds AP3am and AP5 were moderately soluble in aqueous solutions, that is, up to $c_{\mathrm{AP} 3 \mathrm{am}}=1 \times 10^{-3} \mathrm{~mol} \mathrm{dm}^{-3}$ and $c_{\mathrm{AP} 5}=1 \times 10^{-4} \mathrm{~mol} \mathrm{dm}^{-3}$, respectively. Buffered aqueous solutions of the studied compounds were stable for several months and their absorbances were proportional to their concentrations up to $c=3 \times 10^{-5} \mathrm{~mol} \mathrm{dm}^{-3}$. Changes of the UV-vis spectra in response to temperature increases of up to $95^{\circ} \mathrm{C}$ were negligible, and the reproducibility of the UV-vis spectra upon cooling back to $25^{\circ} \mathrm{C}$ was excellent. The UV-vis spectra of new compounds (AP3am, AP5) were similar to previously studied analogues [11] (Supporting Information File 1).

\section{Study of interactions of DBTAA derivatives with ds-DNA/RNA in aqueous medium}

Previous studies [11] revealed intriguing recognition of single stranded DNA dT sequences by AP3 (but not AP6, APH), whereby intercalation of AP3, AP6, APH in double stranded
ct-DNA was excluded. Here, we studied in more detail the interactions of AP3, AP6, APH as well as the novel AP3am and AP5 with a series of synthetic double-stranded polynucleotides.

\section{Thermal denaturation experiments}

Non-covalent binding of ligands to ds-DNA/RNA usually induces stabilization of the ds-helix against thermal denaturation resulting in the increase of DNA/RNA- $T_{\mathrm{m}}$. In particular, thermal stabilization is characteristic for the intercalative binding mode due to the strong aromatic stacking interactions between studied condensed aromatic molecule and adjacent base pairs $[1,16]$.

None of the AP compounds showed any stabilization effect on any of studied ds-polynucleotides, whereas the previously studied DP77 analogue [12] showed a significant stabilization effect. The DP77 analogue essentially differing from the AP series by the presence of two positive charges, one each on side arm (Table 1).

\section{UV-vis titrations and affinity determination}

Titration of the AP series with any studied polynucleotide resulted in a pronounced decrease of the UV-vis absorbance of the DBTAA chromophore at $>300 \mathrm{~nm}$ (Figure 1, Table 2). However, no measurable shifts of the UV-vis absorption maxima for any of the AP series were observed. In contrast, the previously studied analogue DP77 exhibited strong bathochromic shifts of $\left(\Delta \lambda_{346 \mathrm{~nm}}=4-13 \mathrm{~nm}\right.$; pyridinium instead of adenine) [12]. The observation of a hypochromic and not a

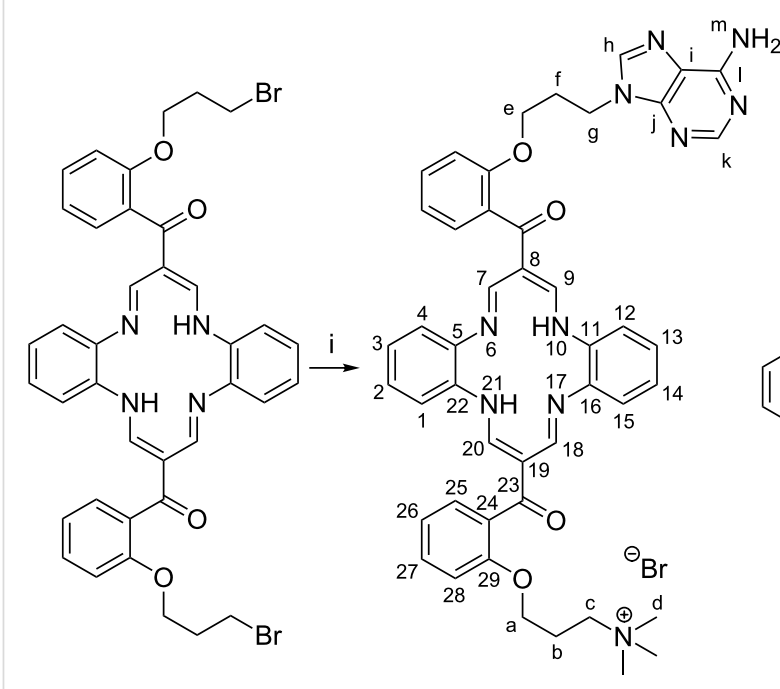

AP3am<smiles>CC(C)Cn1cnc2c(N)ncnc21</smiles>

AP5

Scheme 2: Preparations of the products AP3am and AP5. Starting compounds were synthesized according to previously reported procedures [13,14]. i: (1) adenine, NaH, DMF, (2) trimethylamine, DMF; ii: (1) 9-(5-bromopentyl)adenine [15], potassium carbonate, DMF, (2) 1,5-dibromopentane, potassium carbonate, DMF, (3) pyridine. 
Table 1: The $\Delta T_{\mathrm{m}}{ }^{\mathrm{a}}$ values $\left({ }^{\circ} \mathrm{C}\right.$ ) of studied ds-polynucleotides upon addition of AP3, AP3am AP5, AP6 and APH at pH 7.0 (sodium cacodylate buffer, $\left.I=0.05 \mathrm{~mol} \mathrm{dm}^{-3}\right)$, ratio $r=0.3^{\mathrm{b}}$.

\begin{tabular}{|c|c|c|c|c|c|c|}
\hline & AP3 & AP3am & AP5 & AP6 & APH & DP77 [12] \\
\hline ct-DNA $\left(T_{\mathrm{m}}=79.5^{\circ} \mathrm{C}\right)$ & 0 & 0 & 0 & 0 & 0 & 12.8 \\
\hline poly A - poly $\mathrm{U}\left(T_{\mathrm{m}}=52.7^{\circ} \mathrm{C}\right)$ & 0.5 & 0 & 0 & 0 & 0 & 28.1 \\
\hline poly dA-poly dT $\left(T_{\mathrm{m}}=62.7^{\circ} \mathrm{C}\right)$ & 0.7 & 0 & 0 & 0 & 0 & 12.2 \\
\hline poly dAdT-poly dAdT $\left(T_{\mathrm{m}}=56.0^{\circ} \mathrm{C}\right)$ & $<3$ & $<2$ & - & 0 & 0 & - \\
\hline
\end{tabular}

aError in $\Delta T_{\mathrm{m}}: \pm 0.5^{\circ} \mathrm{C} ;{ }^{\mathrm{b}} \mathrm{r}=$ [compound]/[polynucleotide].

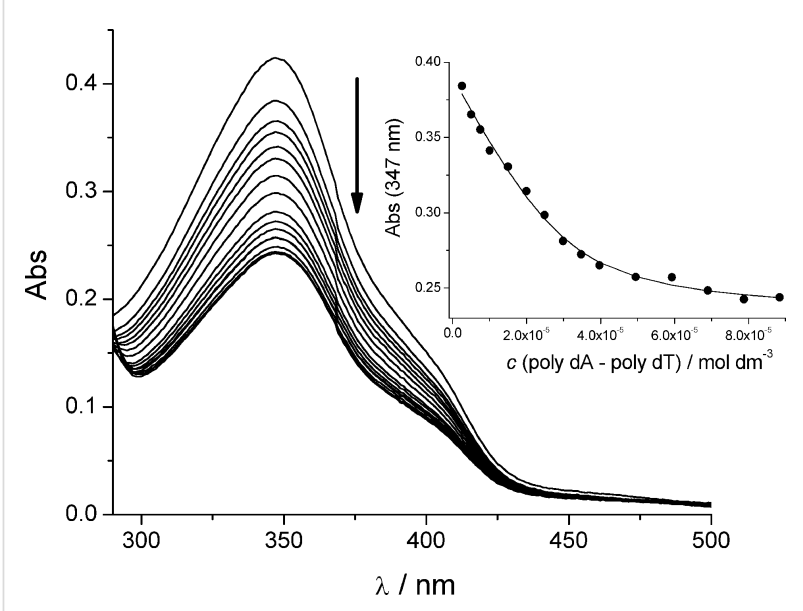

Figure 1: Changes in the UV-vis spectrum of AP3am $\left(c=1.0 \times 10^{-5} \mathrm{~mol} \mathrm{dm}^{-3}\right)$ upon titration with poly $\mathrm{dA}$-poly $\mathrm{dT}$; Inset: dependence of the AP3am absorbance at $\lambda_{\max }=347 \mathrm{~nm}$ on $c$ (poly dA-poly dT), $\mathrm{pH} 7.0$, sodium cacodylate buffer, $I=0.05 \mathrm{~mol} \mathrm{dm}^{-3}$.

bathochromic effect for the AP series suggested a different type of aromatic stacking interaction compared to DP77 (DNA intercalator). There are several possible explanations for the observed hypochromic effect, including the intramolecular stacking of DBTAA with adenine or the intermolecular stacking of two DBTAA chromophores within DNA/RNA grooves, a solvatochromic effect in the DNA/RNA binding site, and even a weak partial intercalation of DBTAA. However, for the accurate elucidation of the precise mechanism, knowledge of the DNA/RNA binding mode is a prerequisite.

Processing of the titration data by means of the Scatchard equation $[17,18]$ gave the binding constants and the density of the binding sites (Table $2, \log K_{\mathrm{S}}$ and ratio $n$, respectively). Data for the APH are not presented in the Table 2 due to the formation of the agglomerates, which cause baseline increases, thus preventing the collection of a sufficient number of data $(>10$ points necessary) for an accurate non-linear fitting.

Examination of the data in Table 2 indicates that all studied compounds showed similar affinity toward ds-DNA and ds-RNA. The density of the binding sites (Table 2, ratio $n$ ) is mostly too high for the intercalative mode of binding $\left(n_{\text {intercal. teor. }}<0.25\right)$. This hints at binding within the grooves of DNA/RNA or agglomeration along the DNA/RNA double helix. The possibility of several simultaneous binding modes is excluded by the isoelliptic points observed in CD experiments, which strongly support one dominant binding mode.

Table 2: Binding constants $\left(\log K_{\mathrm{s}}\right)^{\mathrm{a}}$ and ratios $n^{\mathrm{b}}$ ([bound compound]/[polynucleotide phosphate]) calculated from the UV-vis titrations of AP3, AP3am, AP5 and AP6 with ds-polynucleotides at $\mathrm{pH} 7.0$ (buffer sodium cacodylate, $I=0.05 \mathrm{~mol} \mathrm{dm}^{-3}$ ).

\begin{tabular}{|c|c|c|c|c|c|c|c|c|c|c|c|c|}
\hline & \multicolumn{3}{|c|}{ AP3 } & \multicolumn{3}{|c|}{ AP3am } & \multicolumn{3}{|c|}{ AP5 } & \multicolumn{3}{|c|}{ AP6 } \\
\hline & $\mathrm{H}^{\mathrm{C}}$ & $\log K_{s}$ & $n$ & $\mathrm{H}^{\mathrm{C}}$ & $\log K_{s}$ & $n$ & $\mathrm{H}^{\mathrm{c}}$ & $\log K_{s}$ & $n$ & $\mathrm{H}^{\mathrm{c}}$ & $\log K_{\mathrm{s}}$ & $n$ \\
\hline $\begin{array}{l}\text { poly A- } \\
\text { poly U }\end{array}$ & 53 & 6.0 & 0.6 & 35 & 5.8 & 0.5 & 44 & 6.6 & 0.7 & 64 & 5.7 & 0.7 \\
\hline $\begin{array}{l}\text { poly dA- } \\
\text { poly dT }\end{array}$ & 36 & 6.2 & 0.4 & 40 & 5.9 & 0.3 & 40 & 5.4 & 0.5 & 37 & 5.0 & 0.7 \\
\hline $\begin{array}{l}\text { poly dAdT- } \\
\text { poly dAdT }\end{array}$ & 35 & 6.1 & 0.5 & 30 & 5.5 & 0.6 & $-^{d}$ & $-^{d}$ & $-^{d}$ & $-^{d}$ & $-^{d}$ & $-^{d}$ \\
\hline $\begin{array}{l}\text { poly dG- } \\
\text { poly dC }\end{array}$ & 64 & 5.5 & 0.5 & 35 & 5.7 & 0.5 & 61 & 5.8 & 0.6 & 74 & 5.6 & 0.5 \\
\hline
\end{tabular}

aTitration data were processed according to the Scatchard equation $[17,18]$; ${ }^{\text {Acccuracy }}$ of $n \pm 10-30 \%$, consequently log $K_{\mathrm{s}}$ values vary in the same order of magnitude; $\left.{ }^{\mathrm{C}} \mathrm{H} / \%=(\mathrm{Abs}(\mathbf{A P H}, \mathbf{A P 3}, \mathbf{A P 3 a m}, \mathbf{A P 5}, \mathbf{A P 6})-\mathrm{Abs}(\mathrm{complex})) / \mathrm{Abs}(\mathbf{A P 3}, \mathbf{A P 3 a m}, \mathbf{A P 5}, \mathbf{A P 6})\right) \times 100 ;{ }^{\mathrm{d}}$ Accurate calculation of $\log K_{\mathrm{s}}$ values was hampered by precipitation during titration. 
The thermal stabilization of ds-DNA/RNA is an essential feature of the intercalative binding mode, as well as for many groove binding molecules. The inability of the entire AP series to stabilize ds-DNA/RNA (Table 1), in combination with a considerable binding affinity (Table 2 ) gives rise to the question of the AP series binding mode. To shed more light on the unusual binding process of the AP dyes, it was necessary to assess the structure of the AP dye/polynucleotide complex. Application of the most informative methods like NMR and $\mathrm{X}$-ray crystallography was hampered by the tendency of the AP dye/DNA complexes to form colloidal systems at $c>0.1 \mathrm{mM}$, which neither crystalized nor were suitable for NMR studies due to the extensive broadening and decreasing of proton signals, which eventually merged with the baseline (details about unsuccessful NMR experiments see [11]).

\section{Circular dichroism (CD) experiments}

CD spectropolarimetry offers unique possibilities for the investigation of small molecule-DNA/RNA interactions. The polynucleotide secondary structure is chiral itself, and any binding-induced conformational changes are reflected in the CD spectrum [19]. Moreover, the uniform binding of achiral small molecules within chiral DNA/RNA helix results in an induced CD spectrum (ICD) of the small molecule chromophore, whereby the ICD spectrum range $>300 \mathrm{~nm}$ (at which DNA/ RNA do not absorb) is highly informative about the orientation of the chromophore with respect to DNA/RNA chiral axis $[19,20]$. For instance, the intercalation of an aromatic moiety inside DNA/RNA should result in a weak negative ICD, groove binding would give a strong positive ICD, while the eventual aromatic-dimer formation within polynucleotide grooves should yield the bisignate coupled exciton electronic coupling (EC) ICD bands [20].

The studied DBTAA derivatives are achiral and are not associated with intrinsic CD spectra. Thus, the appearance of ICD bands $>300 \mathrm{~nm}$ upon DNA/RNA binding could be used to estimate the orientation of the DBTAA chromophore in the DNA/ RNA binding site.

The addition of APH, AP3, AP3am, AP5 and AP6 resulted in a decrease of the ds-DNA/RNA CD bands (range from 220 to $300 \mathrm{~nm}$, Supporting Information File 1), whereas the isoelliptic points supported the formation of only one type of the compound/DNA or RNA complex. The intensity decrease of ds-DNA/RNA CD bands is usually associated with the partial disruption of the polynucleotide helical chirality caused by the binding of a small molecule.

The reference compound APH, as well as AP5 and AP6 (Figure 2C) with all studied ds-DNA/RNA give negligible (if any) ICD bands in the range of $>300-450 \mathrm{~nm}$, which along with the moderate affinity (Table 2) and the absence of thermal stabilization (Table 1), suggested a non-specific aggregation of molecules along polynucleotides. Such an unspecific binding mode (possible locations are minor/major groove, not excluding weak partial intercalation of the DBTAA moiety) results in DBTAA chromophores characterized by a variety of orienta-
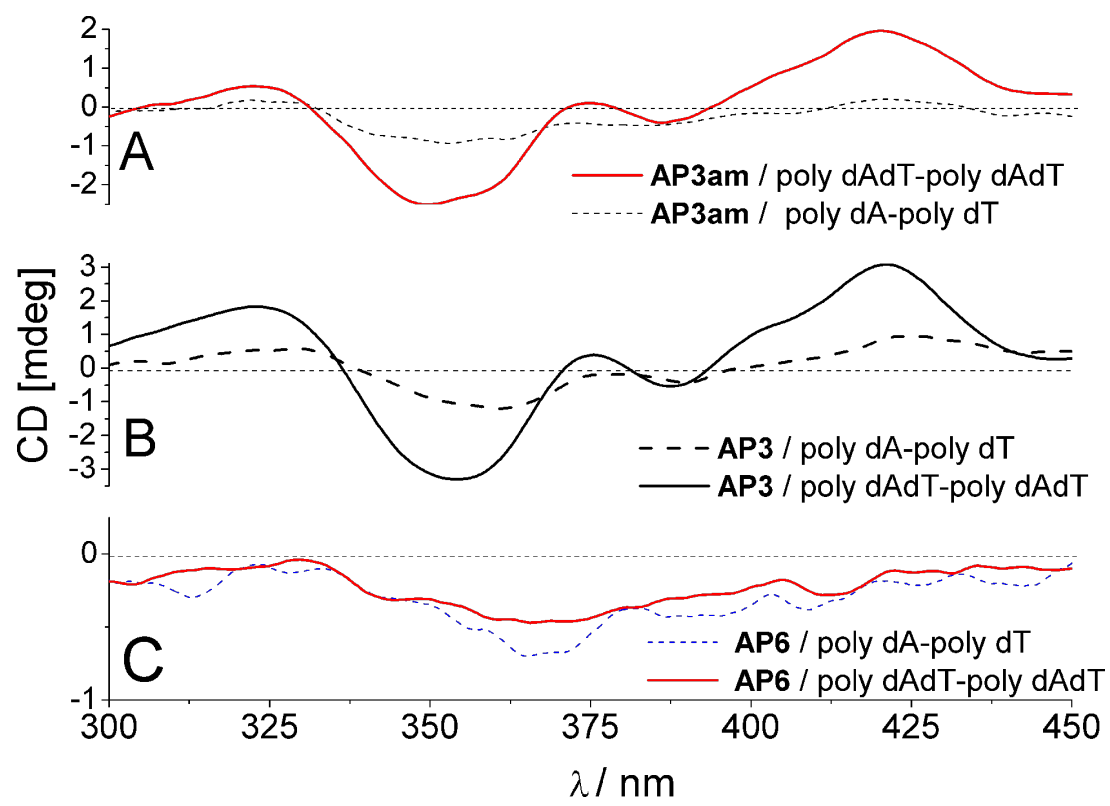

Figure 2: Induced CD bands observed for AP3, AP3am, AP6 for poly dA-poly dT and poly $(\mathrm{dAdT})_{2}\left(c=3.0 \times 10^{-5} \mathrm{~mol}^{\mathrm{dm}} \mathrm{m}^{-3}\right)$. The dG-dC and $\mathrm{rA}-\mathrm{rU}$ polynucleotides did not give any induced (I)CD bands $>300 \mathrm{~nm}$. 
tions oriented variously in respect to the DNA/RNA chiral axis, which can yield the observed weak non-descriptive ICD pattern $[19,20]$.

By contrast with APH/AP5/AP6, the "propyl" analogues AP3 and AP3am revealed significantly different ICD patterns $>300 \mathrm{~nm}$. Strongly induced ICD bands were observed only for AT-containing DNAs (Figure 2A,B), but not for GC-DNA and ds-RNA (Supporting Information File 1). Intriguingly, the ICD pattern observed for AP3 and AP3am (Figure 2A,B; positive-negative-positive sign of ICD bands) were distinctively different from the very weak negative ICD bands of AP5 (Supporting Information File 1) and AP6 (Figure 2C). Moreover, save for AP3, AP3am gave ICD bands (Supporting Information File 1) with mixed sequence ct-DNA (58\% AT base pairs).

Although AP3 and AP3am ICD spectra with AT-DNA closely resemble the ICD spectrum of the previously studied DP77 (no adenine attached to DBTAA), there are several differences between AP3/AP3am and DP77. Only DP77 [12] gives an ICD spectrum for ds-RNA (poly rA-poly rU) and ICD at low $\operatorname{ratios}_{\left[\operatorname{compd}_{/} /[\mathrm{DNA}]\right.}(0.1 ; 0.2)$, which is attributed to DP77-DBTAA intercalation. Under the same conditions the ICD bands of AP3/AP3am exhibit a significant intensity only at $r>0.3$, which strongly corroborates the hypothesis of the dimerization of the DBTAA chromophore within the DNA groove [20]. A more detailed analysis of ICD data revealed that ICD bands of AP3/AP3am were highly sensitive to the secondary structure of DNA/RNA and, in particular, the minor groove properties (Table S1, Supporting Information File 1). For instance, the ICD bands of AP3/AP3am show the strongest intensity for an alternating AT-AT-polynucleotide characterized by a minor groove size of $6.3 \AA$, which is ideal for the accommodation of an aromatic dimer ( $\mathrm{VdW}$ sum of stacked aromatics $\sim 7 \AA$, Figure 4). In contrast to alternating-AT, the homo-polynucleotide poly dA-poly dT minor groove is much narrower $(3.3 \AA)$, and the lower intensity of bisignate ICD bands points to a lower percentage of dimer formation (due to the necessary unwinding and adaptation of homo-polynucleotide to accommodate a DBTAA-dimer). Homo- and alternating-AT-DNA also significantly differ in terms of the charge density and the curvature of the DNA backbone, which can influence interactions of the positively charged arm of AP3/ AP3am with the phosphate backbone and AP3/AP3am-adenine with thymines of the DNA.

The GC-DNA and AU-RNA minor grooves are not suitable for an aromatic dimer binding. In the case of GC-DNA this is due to the steric hindrance of the guanine amino groups inside the groove. In the case of the AU-RNA, it is because of the very wide and shallow shape, which does not support the binding of a small molecule (Table S1, Supporting Information File 1). This is consistent with the fact that no AP3/AP3am ICD bands were observed for GC-DNA and ds-RNA.

In a previous study $\mathbf{A P 3}$ revealed an unprecedented recognition of a dT sequence by the appearance of a specific ICD band, while it did not exhibit an ICD signal for other ss-DNA/RNA [11]. A comparison of ICD bands for various ss- and ds-DNA (Figure 3) revealed that the strong negative band at $350 \mathrm{~nm}$ is characteristic for ds-DNA, whereas the positive bands at 323 and $421 \mathrm{~nm}$ are common for both, ss-dT and ds-AT-DNA. Thus, the negative ICD band at $350 \mathrm{~nm}$ can be assigned to a part of the bisignate coupled exciton electronic coupling (EC) ICD band of the AP3 (also AP3am) dimer inside the ds-DNA minor groove. On the other hand, AP3 binds to poly dT as a single molecule (not stacked with other DBTAA) and, therefore, it is lacking the characteristic bisignate ICD band at $350 \mathrm{~nm}$. Interestingly, the negative ICD band at $350 \mathrm{~nm}$ is also visible for ct-DNA (58\% AT base pairs), which confirms that any AT-DNA sequence even in mixed polynucleotides will give a characteristic ICD pattern.

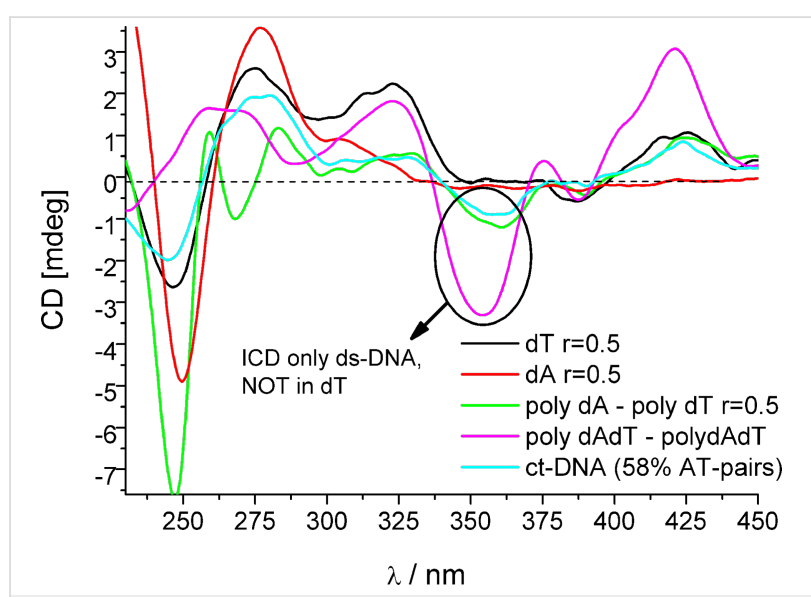

Figure 3: Comparison of AP3 ICD bands for ss-DNA (dA and dT) with alternating- and homo-AT ds-polynucleotides, as well as mixed sequence DNA (ct-DNA, $58 \%$ of AT).

\section{Structure-activity relations of DBTAA-adenine conjugates in AT-DNA binding}

Despite the results described above, it is still not clear whether the origin of the DBTAA-ICD pattern proposed for the AT-DNA recognition is an intermolecularly stacked system formed by two DBTAA moieties or, alternatively, a single intramolecularly stacked DBTAA-adenine molecule. The solubility of the system prevented NMR experiments. So we relied on structural differences (linker length connecting DBTAA and adenine) between AP3/AP3am and AP5/AP6 as free molecules for our proposal of the most likely structure explanation. 
The chosen derivatives (AP5 and AP3) were constructed by starting from the crystal structure of their close analogue [13], and then manually self-folded to bring adenine on top of DBTAA. Finally, their chemical bond lengths and angles were corrected by the MM2-optimization in the software MarvinSuite to assure a realistic presentation (Figure 4). These models serve as a schematic presentation for an easier discussion of the experimental results.

The AP3/AP3am cannot form efficient intramolecular stacks because the AP3/AP3am propyl linker is too short to allow adenine to stack above the DBTAA moiety (Figure 4 lower left). Thus, it can be expected that, given an excess of AP3 over DNA binding sites $(r>0.3)$, two AP3-DBTAA moieties will form $\pi-\pi$ stacked dimers within the DNA minor groove similar to the crystal structure of close analogue (Figure 4, right). Conversely, the AP5 and AP6 aliphatic linkers are long enough to allow self-folding and easy intramolecular $\pi-\pi$ stacking of adenine with DBTAA (Figure 4, upper right). During the binding event to ds-DNA (AT minor groove) AP5 and AP6 have to combine intramolecular (self-folded) and intermolecular (with DNA) interactions, whereby the best compromise could be the binding of self-folded molecules within a DNA minor groove (see schematic presentation in Figure 5).

The reference compound APH has only one side arm interacting with DNA so that a number of orientation options upon DNA/RNA binding is increased, which results in a negligible/ non-descriptive ICD pattern. It should be stressed that the absence of APH-ICD bands emphasizes the importance of adenine in AP3/AP3am for the induction of AT-DNA ICD pattern.

\section{Conclusion}

The AP derivatives presented herein are found to non-covalently bind to ds-DNA/RNA. The absence of bathochromic shifts in UV-vis titrations, the lack of a thermal stabilization effect on any ds-DNA/RNA, as well as the previously reported [11] viscometry and gel electrophoresis results do not support intercalation as the dominant binding mode (not excluding weak partial intercalation of the DBTAA moiety in some cases). Intrinsically achiral, AP-derivatives reveal significantly different induced CD bands upon binding to ds-DNA/RNA. Only DBTAA-propyladenine conjugates (AP3/AP3am) revealed molecular recognition of AT-DNA by the appearance of an ICD band pattern $>300 \mathrm{~nm}$. Significant ICD bands did not appear for other ds-DNA/RNA. A structure-activity relation for the studied series of compounds revealed that the essential structural features for the ICD recognition of AT-DNA are a) the presence of DNA-binding appendages on both DBTAA side chains, i.e., the adenine side chain and the positively charged side chain and $b$ ) the presence of a short propyl linker, which does not support intramolecular aromatic stacking between DBTAA and adenine.

The essential difference between AP3/AP3am and DP77 is that the former give ICD bands exclusively for AT-DNA, while the latter gives various ICD patterns for all ds-DNA and even ds-RNA. Thus DP77 is not suitable for the recognition of AT-DNA.

Furthermore, the ICD patterns of AP3 with ss-DNA (oligo dT) and ds-AT-DNA essentially differ in the appearance of a strong negative band at $350 \mathrm{~nm}$, characteristic for ds-DNA. This band could be used to probe the efficiency of pairing oligo dT
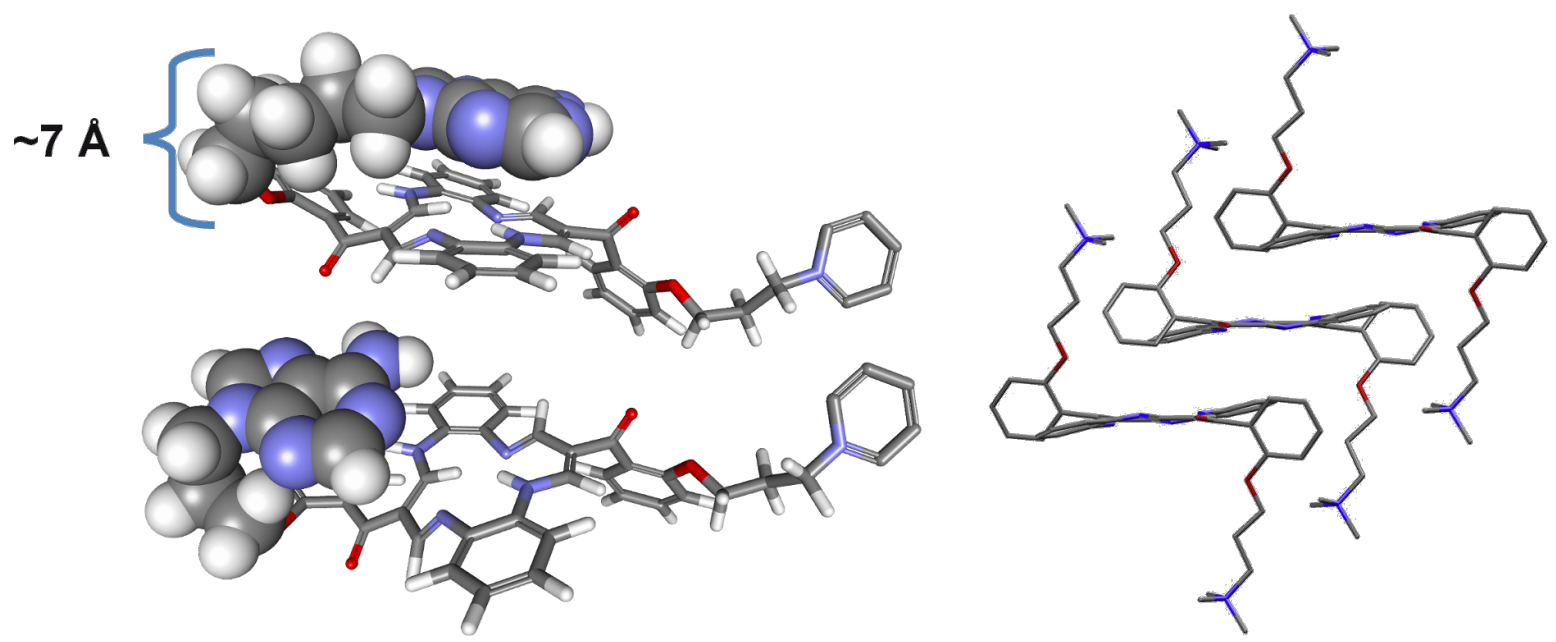

Figure 4: Self-folding of AP5 (upper left - note the stacking of DBTAA and adenine) and AP3 (lower left - note the short linker which does not allow for the stacking of DBTAA and adenine); (right) detail of three molecules packing in crystal by $\pi-\pi$ stacking of parallel DBTAA rings with a distance of ca. $3 \AA$ (see [13] and Figure 8 therein). 


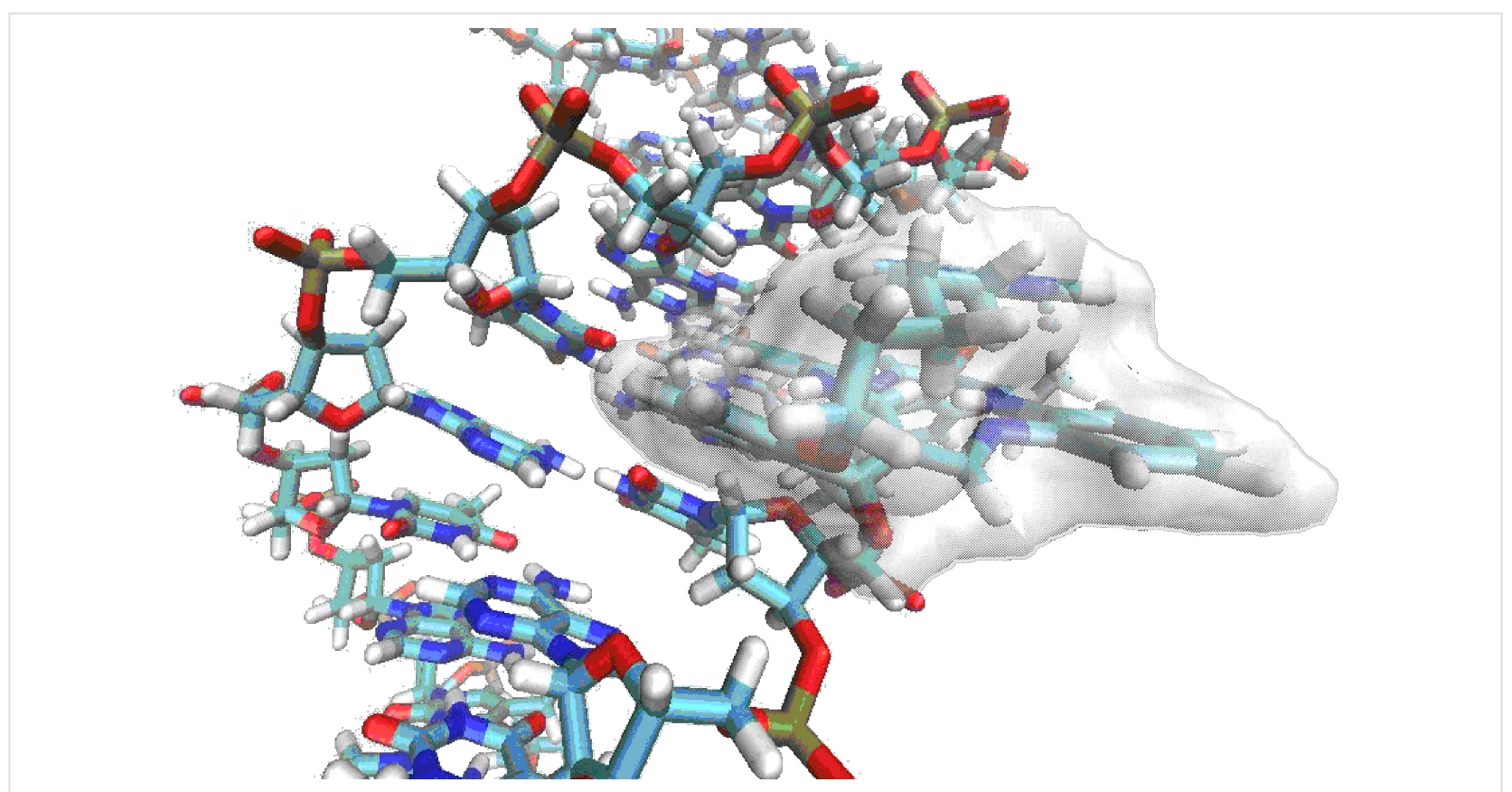

Figure 5: Schematic presentation of self-folded AP5 (free AP5 see Figure 4; upper left) in the minor groove of poly dAdT-poly dAdT. Double stranded DNA (previously used in [6]) was created with the program NUCGEN, a part of the AMBER11 program suite [21]. The self-folded ligand AP5 was docked manually into the poly $(\mathrm{dA}-\mathrm{dT})_{2}$ polynucleotide minor groove by using the program VMD [22], taking into account that VdW radii of DNA and ligand do not overlap.

sequences with complementary $\mathrm{dA}$ or $\mathrm{rA}$ structures, for instance, in any (antisense strategy) developed oligonucleotide, which relies on efficient and precise AT sequence pairing. Namely, the addition of AP3/AP3am to ss-DNA containing an oligo dT sequence should yield the specific ICD pattern of dT among any other ss-DNA/RNA sequence present in solution [11]. The ICD pattern upon the addition of the exclusively matching oligo A sequence should change by the appearance of a strong negative band at $350 \mathrm{~nm}$, which is characteristic for ds-AT-DNA. Another application could be related to oligo (dT)-cellulose commonly used for tRNA purification [23]. In particular, the difference in AP3/AP3am ICD pattern between cellulose-tagged dT and coupled double-stranded oligo dT-rA can be reported and its stability and structure studied in detail by monitoring the changes in ICD shape and intensity.

Furthermore, DBTAA-derivatives are azamacrocyclic ligands and thus have additional potential to bind metal cations [24], such metal complexes offering a variety of different interactions with DNA/RNA. Future prospects also include the synthesis of fluorescent DBTAA derivatives, which are expected to transfer observed intriguing DBTAA-DNA/RNA binding properties in a lower concentration range and broaden the set of DBTAA applications by cell-bioimaging. Such applications are also supported by the preliminary bioactivity screening of the AP-series, which revealed low cytotoxicity toward human cell lines.

\section{Experimental General}

7,16-Bis[2-(3-bromopropoxy)benzoyl]-5,14-dihydrodibenzo $[b, i][1,4,8,11]$ tetraazacyclotetradecine, 7,16-Bis[2hydroxybenzoyl]-5,14-dihydrodibenzo[ $b, i][1,4,8,11]$ tetraazacyclotetradecine and 9-(6-bromopentyl)adenine were prepared by the procedure described earlier [13-15]. All reagents were purchased from commercial sources (Sigma-Aldrich) and were used as received. Solvents were dried by using standard methods and were freshly distilled before use.

${ }^{1} \mathrm{H}$ and ${ }^{13} \mathrm{C}$ NMR were run on Bruker AVANCE II 300 and Bruker AVANCE III 600 spectrometers. Chemical shifts $(\delta)$ are expressed in parts per million and J values in hertz. Signal multiplicities are denoted as s (singlet), $d$ (doublet), $t$ (triplet), $q$ (quartet), and $\mathrm{m}$ (multiplet). The IR-ATR spectra were recorded with a Thermo Fisher Scientific Nicolet IR200. ESI mass spectra were taken on a Bruker Daltonics microTOF-II spectrometer.

\section{Syntheses}

(7-\{2-[3-(Adenin-9-yl)propoxy]benzoyl\}-16- $\{2-[3-(\mathrm{N}, \mathrm{N}, \mathrm{N}-$ trimethylammonium ) propoxy]benzoyl $\}-5,14-d i h y-$ drodibenzo $[b, i][1,4,8,11]$ tetraazacyclotetradecine bromide) (AP3am): Similar as described in [11] a mixture consisting of adenine $(0.175 \mathrm{~g}, 1.298 \mathrm{mmol})$ and $60 \% \mathrm{NaH}(0.039 \mathrm{~g}$, $0.931 \mathrm{mmol})$ in anhydrous DMF $(3 \mathrm{~mL})$ was stirred for $1 \mathrm{~h}$ at 
room temperature. 7,16-Bis[2-(3-bromopropoxy)benzoyl]-5,14dihydrodibenzo $[b, i][1,4,8,11]$ tetraazacyclotetradecine [13] $(0.5 \mathrm{~g}, 0.649 \mathrm{mmol})$ dissolved in hot anhydrous DMF $(40 \mathrm{~mL})$ was added, and the reaction mixture was stirred at $40{ }^{\circ} \mathrm{C}$ for $5 \mathrm{~min}$, then for $3 \mathrm{~h}$ at room temperature. The reaction mixture was then cooled in a freezer and partitioned between dichloromethane $(70 \mathrm{~mL})$ and water $(100 \mathrm{~mL})$. The organic layer was separated, washed with water $(2 \times 100 \mathrm{~mL})$, dried over anhydrous magnesium sulfate, concentrated to a small volume, and chromatographed on a column of silica gel with dichloromethane/methanol (20:0.5 to $20: 1 \mathrm{v} / \mathrm{v})$ as an eluent. The main orange fraction was collected and evaporated to dryness. A residue was dissolved in DMF $(3 \mathrm{~mL})$ and placed in an ice bath. $0.6 \mathrm{~mL}$ of cooled trimethylamine was added, and the mixture was stirred for $5 \mathrm{~h}$ at $50{ }^{\circ} \mathrm{C}$. The excess of trimethylamine was removed under diminished pressure, and $30 \mathrm{~mL}$ of tert-butyl methyl ether was added. Crystallized solid was collected, washed with tert-butyl methyl ether, dried in vacuum, and chromatographed on a column with basic aluminum oxide with dichloromethane/methanol (20:0.5 to 20:2 v/v) as an eluent. The main orange fraction was collected, evaporated to dryness, and dissolved in methanol $(2 \mathrm{~mL})$. An orange-red microcrystalline product was obtained by the slow diffusion of diethyl ether and the drying isolated solid under vacuum. Yield: $0.046 \mathrm{~g}(8 \%) .{ }^{1} \mathrm{H}$ NMR (600 MHz, DMSO- $\left.d_{6}\right) \delta(\mathrm{ppm}) 14.29\left(\mathrm{~m}, 1 \mathrm{H}, \mathrm{H}^{10} / \mathrm{H}^{21}\right)$, $14.20\left(\mathrm{~m}, 1 \mathrm{H}, \mathrm{H}^{10} / \mathrm{H}^{21}\right), 8.55\left(\mathrm{~d}, J=6.7 \mathrm{~Hz}, 2 \mathrm{H},\left\{\mathrm{H}^{7}\right.\right.$, $\left.\left.\mathrm{H}^{9}\right\} /\left\{\mathrm{H}^{18}, \mathrm{H}^{20}\right\}\right), 8.43\left(\mathrm{~d}, J=6.5 \mathrm{~Hz}, 2 \mathrm{H},\left\{\mathrm{H}^{7}, \mathrm{H}^{9}\right\} /\left\{\mathrm{H}^{18}\right.\right.$, $\left.\left.\mathrm{H}^{20}\right\}\right), 7.91\left(\mathrm{~s}, 1 \mathrm{H}, \mathrm{H}^{\mathrm{h}}\right), 7.86\left(\mathrm{~s}, 1 \mathrm{H}, \mathrm{H}^{\mathrm{k}}\right), 7.52\left(\mathrm{~m}, 2 \mathrm{H}, \mathrm{H}^{27}\right.$, $\left.\mathrm{H}^{27}\right)$, $7.39\left(\mathrm{~m}, 2 \mathrm{H}, \mathrm{H}^{25}, \mathrm{H}^{25}\right)$, 7.09-7.31 (m, 12H, $\mathrm{H}^{1}-\mathrm{H}^{4}, \mathrm{H}^{12}-$ $\left.\mathrm{H}^{15}, \mathrm{H}^{26}, \mathrm{H}^{26}, \mathrm{H}^{28}, \mathrm{H}^{28}\right), 7.07$ (s, 2H, H $\left.\mathrm{H}^{\mathrm{m}}\right), 4.09-4.14$ (m, 4H, $\left.\mathrm{H}^{\mathrm{g}}, \mathrm{H}^{\mathrm{a}}\right), 4.03\left(\mathrm{t}, J=5.9 \mathrm{~Hz}, 2 \mathrm{H}, \mathrm{H}^{\mathrm{e}}\right), 3.28\left(\mathrm{~m}, 2 \mathrm{H}, \mathrm{H}^{\mathrm{c}}\right), 2.92(\mathrm{~s}$, $\left.9 \mathrm{H}, \mathrm{H}^{\mathrm{d}}\right), 2.11\left(\mathrm{~m}, 2 \mathrm{H}, \mathrm{H}^{\mathrm{f}}\right), 2.03\left(\mathrm{~m}, 2 \mathrm{H}, \mathrm{H}^{\mathrm{b}}\right) ;{ }^{13} \mathrm{C}$ NMR $(75$ $\left.\mathrm{MHz}, \mathrm{DMSO}-d_{6}\right) \delta(\mathrm{ppm}) 191.2,191.4\left(\mathrm{C}^{23}, \mathrm{C}^{23}\right), 155.7\left(\mathrm{C}^{\mathrm{l}}\right)$, 154.8, 155.0 ( $\left.\mathrm{C}^{29}, \mathrm{C}^{29}\right), 152.3,152.7\left(\mathrm{C}^{7}, \mathrm{C}^{9}, \mathrm{C}^{18}, \mathrm{C}^{22}\right), 152.1$ $\left(\mathrm{C}^{\mathrm{k}}\right), 149.2\left(\mathrm{C}^{\mathrm{j}}\right), 140.4\left(\mathrm{C}^{\mathrm{h}}\right), 136.1,136.3\left(\mathrm{C}^{5}, \mathrm{C}^{11}, \mathrm{C}^{16}, \mathrm{C}^{22}\right)$, $131.4\left(\mathrm{C}^{27}, \mathrm{C}^{27}\right), 129.1,129.2\left(\mathrm{C}^{25}, \mathrm{C}^{25}\right), 128.7,128.8\left(\mathrm{C}^{24}\right.$, $\left.\mathrm{C}^{24^{\prime}}\right), 126.7\left(\mathrm{C}^{2}, \mathrm{C}^{3}, \mathrm{C}^{13}, \mathrm{C}^{14}\right), 120.9,121.2\left(\mathrm{C}^{26}, \mathrm{C}^{26}\right), 118.6$ $\left(\mathrm{C}^{\mathrm{i}}\right), 115.3,115.5\left(\mathrm{C}^{1}, \mathrm{C}^{4}, \mathrm{C}^{12}, \mathrm{C}^{15}\right), 112.7,113.0\left(\mathrm{C}^{28}, \mathrm{C}^{28^{\prime}}\right)$, 110.0, $110.2\left(\mathrm{C}^{18}, \mathrm{C}^{19}\right), 65.1\left(\mathrm{C}^{\mathrm{a}}, \mathrm{C}^{\mathrm{e}}\right), 62.8\left(\mathrm{C}^{\mathrm{c}}\right), 52.0\left(\mathrm{C}^{\mathrm{d}}\right)$, 29.0, $22.5\left(\mathrm{C}^{\mathrm{b}}, \mathrm{C}^{\mathrm{f}}\right)$; ESI-HRMS $(\mathrm{m} / \mathrm{z}): \mathrm{M}^{+}$calcd for $\mathrm{C}_{46} \mathrm{H}_{47} \mathrm{~N}_{10} \mathrm{O}_{4}, 803.378$; found, 803.376; IR-ATR $\left(\mathrm{cm}^{-1}\right)$ : 3525 , $3374,3314,3177,3083,2959,2919,2868,1651,1600,1562$, 1484, 1449, 1417, 1396, 1286, 1263, 1239, 1219.

(7-\{2-[5-(Adenin-9-yl)pentoxy]benzoyl\}-16-\{2-[5-( $N$-pyridini um-1 - yl) pentoxy ] benzoy 1$\}-5,14$ - dihydrodibenzo $[b, i][1,4,8,11]$ tetraazacyclotetradecine bromide) (AP5): Similar as described in [11] a reaction mixture consisting of 7,16-Bis[2-hydroxybenzoyl]-5,14-dihydrodibenzo $[b, i][1,4,8,11]$ tetraazacyclotetradecine $[14](0.2 \mathrm{~g}$, $0.378 \mathrm{mmol})$, anhydrous potassium carbonate $(0.104 \mathrm{~g}$,
$0.757 \mathrm{mmol}$ ), and 9-(6-bromopentyl)adenine [15] (0.054 g, $0.189 \mathrm{mmol})$ in anhydrous DMF $(40 \mathrm{~mL})$ was stirred for $72 \mathrm{~h}$ at room temperature. 1,5-Dibromopentane $(0.618 \mathrm{~mL}, 4.54 \mathrm{mmol})$ and anhydrous potassium carbonate $(0.026 \mathrm{~g}, 0.189 \mathrm{mmol})$ were then added, and the stirring was continued for $24 \mathrm{~h}$ at room temperature. The reaction mixture was partitioned between dichloromethane $(20 \mathrm{~mL})$ and water $(100 \mathrm{~mL})$. A small amount of solid $\mathrm{KBr}$ was added to improve the separation of the phases. The organic layer was separated and washed thoroughly with water $(5 \times 30 \mathrm{~mL})$, dried over anhydrous magnesium sulfate, concentrated to a small volume, and chromatographed on a column of silica gel with dichloromethane/methanol (10:0.6 $\mathrm{v} / \mathrm{v}$ ) as an eluent. The second fraction was collected from the two orange ones which displayed the highest intensity. It was evaporated to dryness, dissolved in $3 \mathrm{~mL}$ of chloroform, and, once again, chromatographed on a column of silica gel with chloroform/methanol (20:0.4 to 20:0.6 v/v) as an eluent. The main fraction was collected, evaporated to dryness, and a solid residue was dissolved in pyridine $(5 \mathrm{~mL})$. The mixture was stirred for $7 \mathrm{~h}$ at $45{ }^{\circ} \mathrm{C}$, then pyridine was removed under diminished pressure, and the solid residue was chromatographed on a column with basic aluminum oxide with dichloromethane/methanol (20:0.5 to $20: 3 \mathrm{v} / \mathrm{v})$ as an eluent. The main orange fraction was collected and evaporated to dryness. An orange-red microcrystalline product was obtained by drying under vacuum. Yield: $0.035 \mathrm{~g}(19 \%)$. ${ }^{1} \mathrm{H}$ NMR (300 MHz, DMSO- $\left.d_{6}\right) \delta(\mathrm{ppm}) 14.26\left(\mathrm{~m}, 2 \mathrm{H}, \mathrm{H}^{10}, \mathrm{H}^{21}\right), 8.95\left(\mathrm{~m}, 2 \mathrm{H}, \mathrm{H}^{\mathrm{f}}\right)$, $8.54\left(\mathrm{tt}, J=7.8 \mathrm{~Hz}, J=1.3 \mathrm{~Hz}, 1 \mathrm{H}, \mathrm{H}^{\mathrm{h}}\right), 8.45\left(\mathrm{~m}, 4 \mathrm{H}, \mathrm{H}^{7}, \mathrm{H}^{9}\right.$, $\left.\mathrm{H}^{18}, \mathrm{H}^{20}\right), 8.05\left(\mathrm{~m}, 2 \mathrm{H}, \mathrm{H}^{\mathrm{g}}\right), 7.95\left(\mathrm{~s}, 1 \mathrm{H}, \mathrm{H}^{\mathrm{n}}\right), 7.86\left(\mathrm{~s}, 1 \mathrm{H}, \mathrm{H}^{\mathrm{q}}\right)$, $7.50\left(\mathrm{~m}, 2 \mathrm{H}, \mathrm{H}^{27}, \mathrm{H}^{27}\right), 7.33(\mathrm{dd}, J=3.7 \mathrm{~Hz}, J=1.8 \mathrm{~Hz}, 1 \mathrm{H}$, $\left.\mathrm{H}^{25} / \mathrm{H}^{25}\right), 7.04-7.26\left(\mathrm{~m}, 15 \mathrm{H}, \mathrm{H}^{1}-\mathrm{H}^{4}, \mathrm{H}^{12}-\mathrm{H}^{15}, \mathrm{H}^{25} / \mathrm{H}^{25}, \mathrm{H}^{26}\right.$, $\left.\mathrm{H}^{26^{\prime}}, \mathrm{H}^{28}, \mathrm{H}^{28^{\prime}}, \mathrm{H}^{\mathrm{s}}\right), 4.43\left(\mathrm{t}, J=7.6 \mathrm{~Hz}, 2 \mathrm{H}, \mathrm{H}^{\mathrm{e}}\right), 4.00(\mathrm{~m}, 4 \mathrm{H}$, $\left.\mathrm{H}^{\mathrm{a}}, \mathrm{H}^{\mathrm{m}}\right), 3.87\left(\mathrm{t}, J=7.3 \mathrm{~Hz}, 2 \mathrm{H}, \mathrm{H}^{\mathrm{i}}\right), 1.78(\mathrm{~m}, 2 \mathrm{H}$, aliphatic chain), 1.59 (m, 6H, aliphatic chain), $1.24(\mathrm{~m}, 4 \mathrm{H}$, aliphatic chain); ${ }^{13} \mathrm{C}$ NMR (75 MHz, DMSO- $\left.d_{6}\right) \delta$ (ppm) 191.3, 191.4 $\left(\mathrm{C}^{23}, \mathrm{C}^{23}\right), 155.7\left(\mathrm{C}^{\mathrm{r}}\right), 155.1,155.1\left(\mathrm{C}^{29}, \mathrm{C}^{29}\right), 152.4,152.5$ $\left(\mathrm{C}^{7}, \mathrm{C}^{9}, \mathrm{C}^{18}, \mathrm{C}^{20}\right), 152.1\left(\mathrm{C}^{\mathrm{q}}\right), 149.3\left(\mathrm{C}^{\mathrm{p}}\right), 145.3\left(\mathrm{C}^{\mathrm{h}}\right), 144.4$ $\left(\mathrm{C}^{\mathrm{f}}\right), 140.2\left(\mathrm{C}^{\mathrm{n}}\right), 136.1\left(\mathrm{C}^{5}, \mathrm{C}^{11}, \mathrm{C}^{16}, \mathrm{C}^{22}\right), 131.3,131.5\left(\mathrm{C}^{27}\right.$, $\left.\mathrm{C}^{27}\right), 129.0,129.2\left(\mathrm{C}^{25}, \mathrm{C}^{25^{\prime}}\right), 128.6\left(\mathrm{C}^{24}, \mathrm{C}^{24}\right), 127.9\left(\mathrm{C}^{\mathrm{g}}\right)$, $126.7\left(C^{2}, C^{3}, C^{13}, C^{14}\right), 120.7\left(C^{26}, C^{26}\right), 118.5\left(C^{0}\right), 115.2$ $\left(\mathrm{C}^{1}, \mathrm{C}^{4}, \mathrm{C}^{12}, \mathrm{C}^{15}\right), 112.5,112.5\left(\mathrm{C}^{28}, \mathrm{C}^{28}\right), 109.9,110.0\left(\mathrm{C}^{8}\right.$, $\left.\mathrm{C}^{19}\right), 67.5,67.5\left(\mathrm{C}^{\mathrm{a}}, \mathrm{C}^{\mathrm{i}}\right), 60.3\left(\mathrm{C}^{\mathrm{e}}\right), 42.4\left(\mathrm{C}^{\mathrm{m}}\right), 21.8,22.4,27.6$, 27.8, 28.9, $30.1\left(\mathrm{C}^{\mathrm{b}}-\mathrm{C}^{\mathrm{d}}, \mathrm{C}^{\mathrm{j}}-\mathrm{C}^{\mathrm{l}}\right)$; ESI-HRMS $(\mathrm{m} / \mathrm{z}): \mathrm{M}^{+}$calcd for $\mathrm{C}_{52} \mathrm{H}_{51} \mathrm{~N}_{10} \mathrm{O}_{4}, 879.409$; found, 879.407; IR-ATR ( $\left.\mathrm{cm}^{-1}\right)$ : 1249 , 1286, 1412, 1446, 1483, 1560, 1588, 1643, 2863, 2935, 3057, 3317.

\section{Spectrophotometric studies}

The UV-vis spectra were recorded on a Varian Cary 100 Bio spectrophotometer and the CD spectra on a JASCO J815 spectrophotometer at $25{ }^{\circ} \mathrm{C}$ with appropriate $1 \mathrm{~cm}$ path quartz 
cuvettes. The study of interactions with DNA and RNA was carried out with aqueous solutions of compounds buffered to pH 7.0 (buffer sodium cacodylate, $I=0.05 \mathrm{~mol} \mathrm{dm}^{-3}$ ).

Polynucleotides were purchased as noted: poly dAdT-poly dAdT, poly dG-poly dC, poly dA-poly dT, poly A-poly U (Sigma-Aldrich, St. Louis. USA), calf thymus (ct)-DNA (Aldrich). Polynucleotides were dissolved in sodium cacodylate buffer, $I=0.05 \mathrm{~mol} \mathrm{dm}^{-3}, \mathrm{pH}$ 7.0. The calf thymus ct-DNA was additionally sonicated and filtered through a $0.45 \mathrm{~mm}$ filter [25]. The polynucleotide concentration was spectroscopically determined as the concentration of nucleobases. Spectrophotometric titrations were performed at pH $7.0\left(I=0.05 \mathrm{~mol} \mathrm{dm}^{-3}\right.$, buffer sodium cacodylate) by adding portions of polynucleotide solution into the solution of the studied compound for UV-vis. $\mathrm{CD}$ experiments were carried out by adding portions of compound stock solution into the solution of polynucleotide. Titration data were processed by the Scatchard equation $[17,18]$. The values for $K_{\mathrm{s}}$ and $n$ given in Table 2 all have satisfactory correlation coefficients $(>0.999)$. The thermal melting curves for DNA, RNA and their complexes with the studied compounds (Table 1 ) were determined as previously described $[16,26]$ by following the absorption change at $260 \mathrm{~nm}$ as a function of the temperature. The absorbance of the ligands was subtracted from every curve, and the absorbance scale was normalized. $T_{\mathrm{m}}$ values are the midpoints of the transition curves determined from the maximum of the first derivative and checked graphically by the tangent method [26]. The $\Delta T_{\mathrm{m}}$ values were calculated by subtracting $T_{\mathrm{m}}$ of the free nucleic acid from $T_{\mathrm{m}}$ of the complex. Every reported $\Delta T_{\mathrm{m}}$ value was the average of at least two measurements. The error of $\Delta T_{\mathrm{m}}$ is $\pm 0.5^{\circ} \mathrm{C}$.

\section{Supporting Information}

\section{Supporting Information File 1}

Additional NMR spectra for new compounds, additional UV-vis and CD spectra.

[http://www.beilstein-journals.org/bjoc/content/ supplementary/1860-5397-10-225-S1.pdf]

\section{Acknowledgements}

Financial support by the Ministry of Science, Education, Sport of Croatia (098-0982914-2918), the Grant (WCh-BW) Jagiellonian University, Krakow, Poland, the European Regional Development Fund, and the Polish Innovation Economy Operational Program (contract POIG.02.01.00-12-023/08) is acknowledged. This work was also supported by FP7-REGPOT-20122013-1, Grant Agreement Number 316289 - InnoMol. We are grateful to Sanja Tomić for providing us with the constructed and optimized structure of poly $(\mathrm{dAdT})_{2}$, previously used in [6].

\section{References}

1. Demeunynck, M.; Bailly, C.; Wilson, W. D., Eds. DNA and RNA Binders; Wiley-VCH: Weinheim, Germany, 2002. doi:10.1002/3527601783

2. Trinquet, E.; Mathis, G. Mol. BioSyst. 2006, 2, 380-387. doi:10.1039/b607152j

3. Tumir, L.-M.; Piantanida, I. Mini-Rev. Med. Chem. 2010, 10, 299-308. doi:10.2174/138955710791330990

4. Garcia-España, E.; Piantanida, I.; Schneider, H.-J. Nucleic Acids as Supramolecular Targets. In Supramolecular Systems in Biomedical Fields; Schneider, H.-J., Ed.; Royal Society of Chemistry: Cambridge, 2013; pp 213-259. doi:10.1039/9781849737821-00213

5. Rohs, R.; West, S. M.; Sosinsky, A.; Liu, P.; Mann, R. S.; Honig, B. Nature 2009, 461, 1248-1253. doi:10.1038/nature08473

6. Tumir, L.-M.; Crnolatac, I.; Deligeorgiev, T.; Vasilev, A.; Kaloyanova, S.; Branilović, M. G.; Tomić, S.; Piantanida, I. Chem. - Eur. J. 2012, 18, 3859-3864. doi:10.1002/chem.201102968

7. Crnolatac, I.; Tumir, L.-M.; Lesev, N. Y.; Vasilev, A. A.; Deligeorgiev, T. G.; Mišković, K.; Glavaš-Obrovac, L.; Vugrek, O.; Piantanida, I. ChemMedChem 2013, 8, 1093-1103. doi:10.1002/cmdc.201300085

8. Grabar Branilović, M.; Tomić, S.; Tumir, L.-M.; Piantanida, I. Mol. BioSyst. 2013, 9, 2051-2062. doi:10.1039/c3mb25578f

9. Tumir, L.-M.; Grabar, M.; Tomić, S.; Piantanida, I. Tetrahedron 2010, 66, 2501-2513. doi:10.1016/j.tet.2010.01.063

10. Tumir, L.-M.; Piantanida, I.; Juranović, I.; Meić, Z.; Tomić, S.; Žinić, M. Chem. Commun. 2005, 2561-2563. doi:10.1039/b500617a

11. Radić Stojković, M.; Škugor, M.; Tomić, S.; Grabar, M.; Smrečki, V.; Dudek, Ł.; Grolik, J.; Eilmes, J.; Piantanida, I. Org. Biomol. Chem. 2013, 11, 4077-4085. doi:10.1039/c3ob40519b

12. Radić Stojković, M.; Marjanović, M.; Pawlica, D.; Dudek, L.; Eilmes, J.; Kralj, M.; Piantanida, I. New J. Chem. 2010, 34, 500-507. doi:10.1039/b9nj00490d

13. Pawlica, D.; Radić Stojković, M.; Dudek, Ł.; Piantanida, I.; Sieroń, L.; Eilmes, J. Tetrahedron 2009, 65, 3980-3989. doi:10.1016/j.tet.2009.03.030

14. Sigg, I.; Haas, G.; Winkler, T. Helv. Chim. Acta 1982, 65, 275-279. doi:10.1002/hlca.19820650128

15. Itahara, T. J. Chem. Soc., Perkin Trans. 2 1996, 2695-2700. doi:10.1039/p29960002695

16. Mergny, J.-L.; Lacroix, L. Oligonucleotides 2003, 13, 515-537. doi:10.1089/154545703322860825

17. Scatchard, G. Ann. N. Y. Acad. Sci. 1949, 51, 660-672.

18. McGhee, J. D.; von Hippel, P. H. J. Mol. Biol. 1976, 103, 679-684.

19. Rodger, A.; Norden, B., Eds. Circular Dichroism and Linear Dichroism; Oxford University Press: New York, 1997.

20. Eriksson, M.; Nordén, B. Linear and Circular Dichroism of Drug-Nucleic Acid Complexes. In Methods in Enzymology; Chaires, J. B.; Waring, M. J., Eds.; Academic Press: San Diego, 2001; Vol. 340, pp 68-98.

21. Structure given by courtesy of Tomić, S.. http://ambermd.org/.

22. Humphrey, W.; Dalke, A.; Schulten, K. J. Mol. Graphics 1996, 14, 33-38. doi:10.1016/0263-7855(96)00018-5

23. Sambrook, J.; Fritsch, E. F.; Maniatis, T., Eds. Molecular Cloning, a laboratory manual; Cold Spring Harbor Laboratory Press: New York, 1989.

24. Lewiński, K.; Eilmes, J. J. Inclusion Phenom. Macrocyclic Chem. 2005, 52, 261-266. doi:10.1007/s10847-004-8025-2

25. Chaires, J. B.; Dattagupta, N.; Crothers, D. M. Biochemistry 1982, 21 , 3933-3940. doi:10.1021/bi00260a005 
26. Piantanida, I.; Palm, B. S.; Čudić, P.; Žinić, M.; Schneider, H.-J.

Tetrahedron 2004, 60, 6225-6231. doi:10.1016/j.tet.2004.05.009

\section{License and Terms}

This is an Open Access article under the terms of the Creative Commons Attribution License

(http://creativecommons.org/licenses/by/2.0), which permits unrestricted use, distribution, and reproduction in any medium, provided the original work is properly cited.

The license is subject to the Beilstein Journal of Organic Chemistry terms and conditions:

(http://www.beilstein-journals.org/bjoc)

The definitive version of this article is the electronic one which can be found at:

doi:10.3762/bjoc. 10.225 